BOFF, Salete Oro; TOCCHETTO, Gabriel Zanatta. Carência de jurisdição sobre edição germinativa do genoma humano: riscos da ausência de ratio jurídica sobre a ferramenta CRISPR. Revista Eletrônica Direito e Política, Programa de Pós-Graduação Stricto Sensu em Ciência Jurídica da UNIVALI, Itajaí, v.15, n.3, $3^{\circ}$ quadrimestre de 2020. Disponível em: www.univali.br/direitoepolitica - ISSN 1980-7791

\title{
CARÊNCIA DE JURISDIÇÃO SOBRE EDIÇÃO GERMINATIVA DO GENOMA HUMANO: RISCOS DA AUSÊNCIA DE RATIO JURÍDICA SOBRE A FERRAMENTA CRISPR
}

\author{
LACK OF JURISDICTION ON GERMINATIVE EDITION OF THE HUMAN \\ GENOME: RISKS OF THE ABSENCE OF A LEGAL RATIONALITY ON THE
} CRISPR TOOL

\author{
Salete Oro Boff ${ }^{1}$ \\ Gabriel Zanatta Tocchetto ${ }^{2}$
}

\section{RESUMO}

A presente análise pretende responder ao problema de pesquisa "É possível verificar que existe carência de jurisdição sobre o assunto da edição germinativa do genoma humano frente às possibilidades colocadas pela ferramenta CRISPR?", o presente trabalho falseia a hipótese de que a soma dos elementos de situação de "estado da arte" da tecnologia, do histórico humano sobre o assunto da genética humana e a regulação aplicada à tecnologia, permitem concluir pela existência de carência de jurisdição sobre edição germinativa do genoma humano. O objetivo geral do trabalho é o de discutir a operação da variação de edição germinativa do genoma humano por parte do sistema jurídico, ou seja, discutir o que esse elemento significa para o direito em si. o método utilizado foi o hipotético dedutivo. O trabalho conclui confirmando a hipótese e respondendo ao problema apresentado de forma positiva.

Palavras-chave: CRISPR; Edição germinativa do genoma humano; Jurisdição; Genoma humano.

\section{ABSTRACT}

This analysis aims to answer the research problem "Is it possible to verify that there is a lack of jurisdiction on the subject of the germinal edition of the human genome in face of the possibilities posed by the CRISPR tool?", the present work falsifies the hypothesis that the sum of the elements of the "state of the art" of technology, the human history of dealing with the subject of human genetics, and the regulation applied to technology, allow us to conclude that there is a lack of jurisdiction over germinal editing of the human genome. The general objective

\footnotetext{
${ }^{1}$ Doutora em Direito-UNISINOS. Estágio Pós-Doutoral-UFSC. Coordenadora e Professora do PPGDireito Mestrado Direito da IMED. Professora da UFFS. Bolsista Pq/CNPq. Linha de Pesquisa "Efetividade do direito, da democracia e da sustentabilidade". Grupo de Pesquisa CNPq "Direitos, Novas tecnologias e Desenvolvimento. Grupo de estudo GEDIPI. Email: salete.oro.boff@gmail.com.

2 Mestre em Direito pela Faculdade Meridional Imed com bolsa CAPES/FAPERGS, Pós Graduando em Direito Empresarial. Advogado. Pesquisador do projeto "A Proteção Jurídica da Inovação Aberta em Novas Tecnologias: Desafios de Gestão para os NITs". Email: gztocchetto@gmail.com
} 
BOFF, Salete Oro; TOCCHETTO, Gabriel Zanatta. Carência de jurisdição sobre edição germinativa do genoma humano: riscos da ausência de ratio jurídica sobre a ferramenta CRISPR. Revista Eletrônica Direito e Política, Programa de Pós-Graduação Stricto Sensu em Ciência Jurídica da UNIVALI, Itajaí, v.15, n.3, $3^{\circ}$ quadrimestre de 2020. Disponível em: www.univali.br/direitoepolitica - ISSN 1980-7791

of the work is to discuss the operation of the variation of germinal edition of the human genome by the legal system, that is, to discuss what this element means for the law itself. The hypothetical deductive method was used. The research concludes by confirming the hypothesis and responding to the problem presented in a positive way.

KEYWORDS: CRISPR; Germinative editing of the human genome; Jurisdiction; Human genome.

\section{INTRODUÇÃO}

O presente artigo tem como foco responder ao problema de pesquisa que se materializa na seguinte pergunta: "É possível verificar que existe carência de jurisdição sobre o assunto da edição germinativa do genoma humano frente às possibilidades colocadas pela ferramenta CRISPR?". O problema de pesquisa pressupõe a ideia de 'carência' de jurisdição no sentido de verificar se há motivos para que o sistema jurídico opere no sentido de criar jurisdição, e não na simples verificação de 'não existência' de jurisdição.

O trabalho testa a hipótese de que a soma dos elementos de situação de 'estado da arte' da tecnologia, do histórico humano de lidar com o assunto da genética humana, e a regulação aplicada à tecnologia, permitem concluir pela existência de carência de jurisdição sobre edição germinativa do genoma humano. É importante notar que a inexistência de ratio jurídica, aqui também chamada de jurisdição, é tratada como um pressuposto que acaba por ser estudado pela seção 3 do presente texto, e deixa para a arguição aqui feita, a discussão sobre a importância, o risco de ausência dessa ratio sobre o assunto abordado.

O método utilizado para falsear a hipótese colocada é o método hipotético dedutivo. Na primeira seção do trabalho serve como redação estruturante dos conceitos e do estado da arte do assunto discutido, a segunda seção traz a premissa maior sobre o assunto da genética humana em termos históricos e, a terceira seção discute o funcionamento do que pode ser chamado de 'regramento' atualmente colocado à edição germinativa do genoma humano fazendo vezes, portanto, de premissa menor. A técnica de pesquisa utilizada foi a bibliográfica em fontes secundárias. 
BOFF, Salete Oro; TOCCHETTO, Gabriel Zanatta. Carência de jurisdição sobre edição germinativa do genoma humano: riscos da ausência de ratio jurídica sobre a ferramenta CRISPR. Revista Eletrônica Direito e Política, Programa de Pós-Graduação Stricto Sensu em Ciência Jurídica da UNIVALI, Itajaí, v.15, n.3, $3^{\circ}$ quadrimestre de 2020. Disponível em: www.univali.br/direitoepolitica - ISSN 1980-7791

O objetivo geral do artigo em tela é discutir a operação da variação de edição germinativa do genoma humano por parte do sistema jurídico, ou seja, discutir o que esse elemento significa para o direito em si. O objetivo geral se desdobra em três objetivos específicos aos quais cada uma das seções do trabalho se dedica a alcançar, sendo eles o de abordar o estado da arte da edição germinativa do genoma humano, discutir o significado histórico do assunto da genética humana e, por último, discutir o que trata atualmente as limitações operacionais da variação em epígrafe.

Importante a menção de que o termo 'edição germinativa do genoma humano' e o termo 'edição genética hereditária do genoma humano' são utilizados como equivalentes no desenvolvimento do texto. $O$ presente trabalho se justifica em decorrência da relevância que a edição genética hereditária do genoma humano possui, em contraste com a fragilidade que as ferramentas de controle dessa inovação possuem em nível mundial.

\section{OS DESAFIOS DA EDIÇÃo GENÉTICA HEREDITÁRIA}

A engenharia genética, como mecanismo científico, não se limita ao uso de uma tecnologia ou mecanismo em específico para existir como técnica. No entanto, no contexto temporal no qual a presente pesquisa se desenvolve (em 2020), não faz sentido fático-científico discutir a edição genética de características hereditárias no genoma humano sem lidar com a ferramenta que ocupa o papel de protagonista das novas descobertas e expectativas, a ferramenta CRISPR (Clustered Regularly Interspaced Short Palindromic Repeats) ${ }^{3}$, que na sua forma denominada CRISPR tipo II, frequentemente associada à proteína Cas9 ${ }^{4}$, gerou enorme alvoroço na comunidade científica.

CRISPR-Cas9 can pinpoint important but tiny gene sequences in our vast genomes, the genetic equivalent of finding a needle in a haystack. Once there, it can erase

\footnotetext{
3 Sigla que se traduz como: Repetições Palindrômicas Curtas Agrupadas e Regularmente Interespaçadas.

4 "Cas" indica exatamente "CRISPR assossiated", ou seja, a proteína Cas9 é simplesmente a proteína indicada com o número 9 que se denomina exatamente por estar associada ao CRISPR. $O$ terceiro elemento dessa fórmula é um elemento chamado de tracrRNA, que é em si o mecanismo programável que permite grande parte das aplicações da tecnologia.
} 
BOFF, Salete Oro; TOCCHETTO, Gabriel Zanatta. Carência de jurisdição sobre edição germinativa do genoma humano: riscos da ausência de ratio jurídica sobre a ferramenta CRISPR. Revista Eletrônica Direito e Política, Programa de Pós-Graduação Stricto Sensu em Ciência Jurídica da UNIVALI, Itajaí, v.15, n.3, $3^{\circ}$ quadrimestre de 2020. Disponível em: www.univali.br/direitoepolitica - ISSN 1980-7791

and/or change A's, C's, G's or T's, or even larger genomic regions, in surprisingly precise ways. CRISPR can literally rewrite the genomic book inside of us. ${ }^{5}$

A história da ferramenta hoje denominada CRISPR não é exatamente uma história de puro e simples descobrimento científico de uma ferramenta e seus potenciais, mas uma história de sucessivo e somático trabalho de diversos cientistas sem a existência de qualquer noção, em muitos dos passos desse desenvolvimento, de que o conhecimento dessa ferramenta tomaria o papel de protagonista dos desenvolvimentos em edição genética que toma hoje ${ }^{6}$.

O trabalho sobre o CRISPR inicia com anotações derivadas do encontro acidental de repetições palindrômicas ${ }^{7}$ no material genético de micróbios resistentes ao ambiente salgado do mar mediterrâneo em $1989^{\circ}$, passa por momentos em específico onde se descobre a função dessas repetições palindrômicas interespaçadas - que servem como uma forma de mecanismo de defesa para os microorganismos - em $2003^{9}$, pelo acontecimento de diversos estudos da ferramenta in vitro, até o acontecimento da descoberta dos potenciais da ferramenta, protagonizado por Emmanuelle Marie Charpentier e Jennifer Doudna em 2012 ${ }^{10}$. Já no ano subsequente, em 2013, o CRISPR entrou em um estado "viral", tanto no meio acadêmico quanto para a população em geral.

In early 2013, Google searches for "CRISPR" began to skyrocket - a trend that has continued unabated. Within a year, investigators had reported the use of CRISPR-based genome editing in many organisms - including yeast, nematode, fruit fly, zebrafish, mouse, and monkey. Scientific

\footnotetext{
5 Tradução livre: CRISPR-Cas9 pode identificar sequências genéticas importantes, porém minúsculas, em nossos vastos genomas, o equivalente genético de encontrar uma agulha em um palheiro. Uma vez lá, ele pode apagar e/ou alterar regiões de As, Cs, Gs ou Ts ou regiões genômicas ainda maiores, de maneiras surpreendentemente precisas. O CRISPR pode literalmente reescrever o livro genômico dentro de nós. KNOEPFLER, Paul. GMO Sapiens: The Life-Changing Science of Designer Babies. Singapura: World Scientific, 2016. p. 11.

6 DoudnA, Jeniffer A.; STERnBerg, Samuel H.. A Crack in Creation, Gene editing and the unthinkable power to control evolution. Boston: Mariner Books, 2017.

7 Palíndromo é uma sequência de itens (objetos, símbolos, números, ou mesmos nucleotídeos) que apresenta a mesma sequência quando lida de qualquer das extremidades em direção a outra. Um exemplo de palíndromo é a palavra "ovo".

${ }^{8}$ LANDER, Eric S. The heroes of CRISPR. Cell, v. 164, n. 1-2, p. 18-28, 2016. p. 18.

${ }^{9}$ LANDER, Eric S. The heroes of CRISPR. Cell, v. 164, n. 1-2, p. 18-28, 2016. p. 20

10 LANDER, Eric S. The heroes of CRISPR. Cell, v. 164, n. 1-2, p. 18-28, 2016. p. 24.
} 
BOFF, Salete Oro; TOCCHETTO, Gabriel Zanatta. Carência de jurisdição sobre edição germinativa do genoma humano: riscos da ausência de ratio jurídica sobre a ferramenta CRISPR. Revista Eletrônica Direito e Política, Programa de Pós-Graduação Stricto Sensu em Ciência Jurídica da UNIVALI, Itajaí, v.15, n.3, $3^{\circ}$ quadrimestre de 2020. Disponível em: www.univali.br/direitoepolitica - ISSN 1980-7791

and commercial interest in potential applications in human therapeutics and commercial agriculture began to heat up as did social concerns about the prospect that the technology could be used to produce designer babies. ${ }^{11}$

O grande paradigma posado pela tecnologia pode ser tratado exatamente na afirmação que menciona os 'designer babies' ${ }^{12}$, pelo fato de que muitos dos aspectos que as possibilidades colocam à edição genética passam a colocar o ser humano no centro de tudo como objeto de trabalho, em especial no sentido de edições genéticas hereditárias. A emergência do debate bioético é conhecida também por uma das descobridoras do potencial da tecnologia (e co-responsável pela moratória que será discutida mais adiante no presente trabalho), e ela se resume de forma muito apropriada na menção que a autora cita ter ouvido em uma conversa no ano de 2015 em Napa Valley na Califórnia: "Someday we may consider it unethical not to use germline editing to alleviate human suffering"13, exatamente pelo fato de que o potencial de solução das mais de duas mil enfermidades, malformações e outros defeitos humanos que têm causa genética ${ }^{14}$ poderiam eventualmente ser objeto de tratamentos cuja consequência seria a diminuição do sofrimento humano.

Pensar no ser humano como objeto de pesquisa remete a memória histórica do ser humano aos velhos pensamentos eugênicos de Galton, à suástica e ao poder de "libertar com trabalho", mas a objetificação do humano é um conceito que está uma construção lógica de distância de todos aqueles que vislumbram o ato de gerar (ou adotar) uma prole ao tempo de imaginar e pensar em programar o

11 Tradução livre: No início de 2013, as pesquisas do Google por "CRISPR" começaram a disparar - uma tendência que continuou inabalável. Em um ano, os pesquisadores relataram o uso da edição do genoma baseado no CRISPR em muitos organismos - incluindo leveduras, nematóides, mosca da fruta, peixe-zebra, camundongo e macaco. O interesse científico e comercial em possíveis aplicações na terapêutica humana e na agricultura comercial começou a esquentar assim como as preocupações sociais sobre a perspectiva de que a tecnologia pudesse ser usada para produzir bebês de geneticamente alterados. LANDER, Eric S. The heroes of CRISPR. Cell, v. 164 , n. $1-2$, p. $18-28,2016$. p. 26.

$12 \mathrm{O}$ termo indica bebês geneticamente alterados a partir de escolhas por quem os desenhou. Pelo fato de que uma tradução literal para o português (bebês de desenho) não expressa adequadamente o termo, o texto faz uso da versão inglesa da expressão.

13 Tradução livre: Um dia poderemos considerar antiético não utilizar edições genéticas em linha germinativa [de características hereditárias] para aliviar o sofrimento humano. DOUDNA, Jeniffer A.; STERnBERG, Samuel H. A Crack in Creation, Gene editing and the unthinkable power to control evolution. p. 154.

${ }^{14}$ AYALA, Francisco José. ¿Clonar Humanos? Ingeniería genética y futuro de la humanidad. Madrid: Alianza editorial, 2017. p. 103. 
BOFF, Salete Oro; TOCCHETTO, Gabriel Zanatta. Carência de jurisdição sobre edição germinativa do genoma humano: riscos da ausência de ratio jurídica sobre a ferramenta CRISPR. Revista Eletrônica Direito e Política, Programa de Pós-Graduação Stricto Sensu em Ciência Jurídica da UNIVALI, Itajaí, v.15, n.3, $3^{\circ}$ quadrimestre de 2020. Disponível em: www.univali.br/direitoepolitica - ISSN 1980-7791

futuro da sua prole, ou seja, o ato de desejar um ser humano que não é capaz de consentir para a relação de desejo, está ao alcance de uma construção lógica para a denominação desse desejo como objetificação. O ser humano é objetificado pelo ser humano exatamente pelo fato de que a relação do humano com o ambiente (ou seja, tudo o que não é o indivíduo em si) é uma relação que necessariamente passa por uma externalização do que o ego constrói ${ }^{15}$

\begin{abstract}
As figuras simbólicas facilmente se tornam silhuetas de pesadelo. Disso é testemunha essa velha imagem da sabedoria, tão frequentemente traduzida, nas gravuras alemãs, por um pássaro de pescoço comprido cujos pensamentos, ao se elevarem lentamente do coração à cabeça têm tempo para serem pesados e refletidos; símbolos cujos valores se entorpecem por serem demasiado acentuados: o longo caminho de reflexão torna-se, na imagem, o alambique de um saber sutil, instrumento que destila as quintessências. O pescoço do Gutemensch alongase indefinidamente a fim de melhor configurar, além da sabedoria, todas as mediações reais do saber; e o homem simbólico torna-se um pássaro fantástico cujo pescoço desmesurado se dobra mil vezes sobre si mesmo - ser insensato, a meio caminho entre o animal e a coisa, mais próximo dos prestígios próprios à imagem que do rigor de um sentido. ${ }^{16}$
\end{abstract}

O grande ponto é que, no ato de considerar o humano como algo inerentemente reconhecível e palpável, no sentido de que é fácil para o ser humano reconhecer outro humano, a sociedade negligencia constantemente a conceituação desse ser, e trabalha em si com a pressuposição desse conceito de uma forma geral. Em termos biológicos gerais, é muito importante se ter em mente o fato de que, em regra, os seres vivos conhecidos são essencialmente (representados por percentuais de seu peso) compostos por $70 \%$ de oxigênio, $18 \%$ de carbono, $10 \%$ de hidrogênio e quantidades pequenas de cálcio, potássio, nitrogênio e outros elementos ${ }^{17}$, o que significa que em termos de composição química, os seres vivos em si são muito semelhantes. Quando se fala em genética, é interessante ver 0 quão pequenas podem ser as diferenças de seres

${ }^{15}$ GOULDNER, Alvin W. The norm of reciprocity: A preliminary statement. American sociological review, p. 161-178, 1960. p. 177/178

16 FOUCAULT, Michel. História da Loucura. Tradução de José Teixeira Coelho Neto. São Paulo: Perspectiva, 2017. p. 19.

${ }^{17}$ AYALA, Francisco José. ¿Clonar Humanos? Ingeniería genética y futuro de la humanidad. p. 40. 
BOFF, Salete Oro; TOCCHETTO, Gabriel Zanatta. Carência de jurisdição sobre edição germinativa do genoma humano: riscos da ausência de ratio jurídica sobre a ferramenta CRISPR. Revista Eletrônica Direito e Política, Programa de Pós-Graduação Stricto Sensu em Ciência Jurídica da UNIVALI, Itajaí, v.15, n.3, $3^{\circ}$ quadrimestre de 2020. Disponível em: www.univali.br/direitoepolitica - ISSN 1980-7791

fenotipicamente parecidos, "Cuando se consideran todas sus proteínas, el hombre y el chipancé diferen, de promedio, en uno de cada cien aminoácidos." ${ }^{18}$

Mas o que acontece quando uma inovação tecnológica permite a criação de um ser humano, com características físicas de humano, e intelecto de um outro animal qualquer? Ainda, considerar o intelecto como elemento da essência humana desumaniza o humano que possui deficiência ou incapacidade cognitiva? O que aconteceria se os 'ratos de laboratório' tivessem capacidade cognitiva equivalente à humana?

Overall, my studies of the N-Myc GM mice provided important insights into normal brain development and also into that of brain tumors. As a scientist, that outcome felt, and still feels like an important accomplishment. At the same time, on a personal level I admittedly felt a bit unsettled for a time by my initial foray into creating a GMO in the form of these mice. You alter or remove a gene and you can change a creature's brain size? That was positive scientifically and at the same time uncomfortable on some levels personally. ${ }^{19}$

O fechamento conceitual do humano é algo que precisa colocar na balança elementos importantes ao desenvolvimento humano: uma vez que se abstrai a essência humana a qualquer derivação do que é colocado como genoma humano e se impossibilita o desenvolvimento de testes com esse genoma. Essa decisão custa, historicamente, um número imensurável de vidas, uma vez que o estudo genético possui potencial de curar as mais diversas doenças humanas que se relacionam com características genéticas ${ }^{20}$. Ao mesmo tempo que uma conceituação muito reduzida de uma eventual essência do ser humano pode custar o sofrimento de inúmeros indivíduos e manchar a própria história da

\footnotetext{
${ }^{18}$ Tradução livre: Quando se consideram todas as suas proteínas, o homem e o chipanzé diferem, em média, em um a cada cem aminoácidos. AYALA, Francisco José. ¿Clonar Humanos? Ingeniería genética y futuro de la humanidad. p. 42

19 Tradução livre: No geral, meus estudos sobre os camundongos GM N-Myc forneceram informações importantes sobre o desenvolvimento normal do cérebro e também sobre os tumores cerebrais. Como cientista, esse resultado foi sentido e ainda parece uma conquista importante. Ao mesmo tempo, em um nível pessoal eu reconhecidamente me senti um pouco perturbado por um tempo pela minha incursão inicial em criar um OGM na forma desses ratos. Você altera ou remove um gene e pode mudar o tamanho do cérebro de uma criatura? Isso foi positivo cientificamente e ao mesmo tempo desconfortável em alguns níveis pessoalmente. KNOEPFLER, Paul. GMO Sapiens: The Life-Changing Science of Designer Babies. Singapura: World Scientific, 2016. p. 151.

${ }^{20}$ KNOEPFLER, Paul. GMO Sapiens: The Life-Changing Science of Designer Babies. Singapura: World Scientific, 2016. p. 12.
} 
BOFF, Salete Oro; TOCCHETTO, Gabriel Zanatta. Carência de jurisdição sobre edição germinativa do genoma humano: riscos da ausência de ratio jurídica sobre a ferramenta CRISPR. Revista Eletrônica Direito e Política, Programa de Pós-Graduação Stricto Sensu em Ciência Jurídica da UNIVALI, Itajaí, v.15, n.3, $3^{\circ}$ quadrimestre de 2020. Disponível em: www.univali.br/direitoepolitica - ISSN 1980-7791

edição gênica como um experimento de proporções nazistas, como será discutido no presente trabalho.

Já é velho no meio científico o argumento de que "bom" e "ruim" não são conceitos absolutos, mas existem elementos fáticos que são capazes de elevar a relatividade desses elementos. Ao considerar a alteração genética como um mecanismo factível de possibilidade de cura de doenças causadas por elementos genéticos, se olvida o fato de que a ideia de doença também é um elemento relativizável.

Alguns anos atrás, um casal de lésbicas decidiu ter um filho, de preferência surdo. As duas parceiras eram surdas, e com orgulho. Tal como outros membros da comunidade do orgulho dos surdos, Sharon Duchesnau e Candy Mccullough consideravam a surdez um traço de identidade cultural e não uma deficiência a ser curada. ${ }^{21}$

É possível verificar a falta de um sentido como algo positivo em um ser humano, e isso é um problema que mostra quão profunda a questão colocada à edição genética pode chegar. Ao tempo que ela pode servir para curar o câncer, ela pode servir ao aumento da inteligência, perda de um sentido, manutenção de uma situação de nanismo em gerações de uma família e, porque não, para produzir traços de menor inteligência que gerem algo como uma felicidade induzida pela falta de entendimento contextual. O que obsta o humano de colocar 'soma'22 dentro de seu próprio código genético?

Ligando ao exposto por Habermas ${ }^{23}$, os mecanismos disponíveis (e, conforme mencionado, já utilizados até certo ponto) mudam completamente o status quo da relação entre pais e filhos, considerando os mecanismos que estão na iminência de estarem à disposição da humanidade (pode ser que a relação de existência entre pais e filhos chegue mais perto à relação de um autor com sua

\footnotetext{
${ }^{21}$ SANDEL, Michael. Contra a Perfeição, ética na era da engenharia genética. Traduzido por Ana Carolina Mesquita. Rio de Janeiro: Civilização Brasileira, 2013. p. 15

22 Soma é uma droga sintética, presente na obra Admirável Mundo Novo. O comprimido chamado atua reduzindo a ansiedade, estresse e outros sentimentos negativos dos personagens, deixandoos em estado de relaxamento e alegria/felicidade plastificada e artificial. HUXLEY, Aldous. Brave New World. London: Vintage Books, 1994.
}

23 HABERMAS, Jürgen. O Futuro da Natureza Humana, a caminho de uma eugenia liberal? Tradução de Maria Benedita Bettencourt. Coimbra: Almedina, 2006. 
BOFF, Salete Oro; TOCCHETTO, Gabriel Zanatta. Carência de jurisdição sobre edição germinativa do genoma humano: riscos da ausência de ratio jurídica sobre a ferramenta CRISPR. Revista Eletrônica Direito e Política, Programa de Pós-Graduação Stricto Sensu em Ciência Jurídica da UNIVALI, Itajaí, v.15, n.3, $3^{\circ}$ quadrimestre de 2020. Disponível em: www.univali.br/direitoepolitica - ISSN 1980-7791

obra literária). Nesse sentido, necessário destacar que, por meio de pesquisas genéticas em relação à possibilidade de cada uma das parceiras terem um filho surdo, e, após a procura de um doador de esperma que tivesse altas chances de gerar esse resultado, as mães obtiveram sucesso no ato de gerar uma criança com a condição de surdez ${ }^{24}$.

Considerando que a edição genética pode levar o 'humano' a caminhos tão opostos e a desenvolvimentos de características quaisquer, ao tempo que a humanidade não carrega consigo um conceito de "o que é ser humano", o quanto será possível alargar esse conceito para observar esse problema? É observável que ao tempo que é possível que uma tentativa de curar o câncer para as futuras gerações seja algo consensual em relação ao desenvolvimento de tecnologia de alteração genética, é verificável que ferramentas como o CRISPR podem servir à acentuação das diferenças entre humanos (paradoxoalmente), isso sem contar com resultados indesejados relativos ao insucesso de edições.

\begin{abstract}
What does "better than human" or $\mathrm{h}+$ really mean? More disease resistant? Smarter? Better parent? Kinder? Wiser? Can we genetically modify humans to attain such goals? And can those new traits conveying the new, better phenotypes be inherited? Some might say that transhumanism fueled by genetics technology poses transcendent risks as well. What if your smarter $\mathrm{h}+$ human is inclined to mental illness? There is some evidence that intelligence correlates with mental illness. What if your $\mathrm{h}+$ human that can never get Alzheimer's or autism is much less kind than the average person today? Perhaps even inclined to cruelty ${ }^{25}$
\end{abstract}

Dessa forma, é verificável que, na ausência de um conceito de humano, até mesmo a intelectualidade pode ser relativizável, e a ideia de humano como humano se esvazia em si mesma, em um contexto no qual o ser humano, sem

\footnotetext{
${ }^{24}$ SANDEL, Michael. Contra a Perfeição, ética na era da engenharia genética. Traduzido por Ana Carolina Mesquita. Rio de Janeiro: Civilização Brasileira, 2013. p. 16.

${ }^{25}$ Tradução livre: O que significa "melhor que o humano" ou o $h+$ ? Mais resistente a doenças? Mais esperto? Melhor pai? Mais gentil? Mais sábio? Podemos modificar geneticamente os seres humanos para atingir esses objetivos? E essas novas características que transmitem os novos e melhores fenótipos podem ser herdadas? Alguns podem dizer que o transhumanismo alimentado pela tecnologia genética também apresenta riscos transcendentais. $\mathrm{E}$ se o seu humano $\mathrm{h}+$ mais inteligente estiver inclinado à doença mental? Existem algumas evidências de que a inteligência se correlaciona com a doenças mentais. E se o seu humano $h+$ que nunca pode ter Alzheimer ou autismo é muito menos gentil do que a pessoa comum hoje em dia? Talvez até inclinado à crueldade? KNOEPFLER, Paul. GMO Sapiens: The Life-Changing Science of Designer Babies. Singapura: World Scientific, 2016. p. 183.
} 
BOFF, Salete Oro; TOCCHETTO, Gabriel Zanatta. Carência de jurisdição sobre edição germinativa do genoma humano: riscos da ausência de ratio jurídica sobre a ferramenta CRISPR. Revista Eletrônica Direito e Política, Programa de Pós-Graduação Stricto Sensu em Ciência Jurídica da UNIVALI, Itajaí, v.15, n.3, $3^{\circ}$ quadrimestre de 2020. Disponível em: www.univali.br/direitoepolitica - ISSN 1980-7791

possuir uma definição biológica objetiva, sem considerar intelectualmente as suas características e esforçar-se a entendê-las, encontra-se em um turbilhão, no qual se mostra mais do que necessária uma construção que o permita trabalhar com a inovação que ele mesmo gera.

É importante notar que a definição do humano como objeto da edição genética, por mais que carregue uma enorme carga de significância (quem sabe a maior carga das questões que podem ser colocadas conceitualmente à edição) e abertura para discussões sobre a edição genética a partir das possibilidades que as novas ferramentas colocam ao ser humano, representa somente um dos desafios colocados ao contexto. Nesse sentido, desconsiderando por motivos metodológicos o problema lógico de alocar esse problema sem solucionar o significado de 'humano' de forma científica, analisar-se-á como a edição genética de características hereditárias em humanos carrega consigo o problema bioético dos direitos do objeto da edição, que vão desde o consentimento até os direitos reprodutivos de indivíduos que têm para si as consequências de decisões tomadas sobre seu material genético.

\section{EUGENIA E FENÓTIPOS: POSSÍVEL ERRO HISTÓRICO NO USO DOS CONHECIMENTOS CIENTÍFICOS SOBRE GENÉTICA}

Eugenia é um termo cuja etimologia designa a ideia de 'boa raça' ${ }^{26}$, um termo que foi cunhado por Francis Galton ${ }^{27}$ no ano de 1883 como consequência de sua dedicação à teoria da evolução desencadeada pela leitura do texto "A Origem das Espécies", escrito por Charles Darwin, no ano de $1859^{28}$. Com laços de parentesco com Darwin, Galton cumpriu um papel importante em um dos períodos que pode ser tratado como maior evidência histórica de que a autoridade do argumento científico, quando essa ciência é desenvolvida de forma incorreta, pode virar uma ferramenta de propagação de atos absurdos e ilógicos.

\footnotetext{
26 MUKHERJEE, Siddhartha. The Gene, an intimate history. London: Penguin Random House UK, 2016. p. 67.

27 Apesar de mencionar a data da primeira edição da obra de Galton, o presente trabalho faz uso da publicação da terceira edição da obra do autor por motivos de disponibilidade do texto. GALTON. Inquiries Into Human Faculty and Its Development. Londres: Everyman, 1907.

${ }^{28}$ MUKHERJEE, Siddhartha. The Gene, an intimate history. p. 65
} 
BOFF, Salete Oro; TOCCHETTO, Gabriel Zanatta. Carência de jurisdição sobre edição germinativa do genoma humano: riscos da ausência de ratio jurídica sobre a ferramenta CRISPR. Revista Eletrônica Direito e Política, Programa de Pós-Graduação Stricto Sensu em Ciência Jurídica da UNIVALI, Itajaí, v.15, n.3, $3^{\circ}$ quadrimestre de 2020. Disponível em: www.univali.br/direitoepolitica - ISSN 1980-7791

Por trás do termo 'eugenia' existe um vasto contexto de práticas científicas duvidosas, levadas a cabo a partir de métodos incapazes de produzir qualquer sentido de estruturação cientificamente válida ${ }^{29}$, mas que de forma alguma podem ser consideradas socialmente inócuas.

All creatures would agree that it was better to be healthy than sick, vigorous than weak, well-fitted than ill-fitted for their part in life; in short, that it was better to be good rather than bad specimens of their kind, whatever that kind might be. So with men. [...] A considerable list of qualities can easily be compiled that nearly everyone except "cranks" would take into account when picking out the best specimens of his class. It would include health, energy, ability, manliness and courteous disposition. ${ }^{30}$

A eugenia proposta por Galton parte do pressuposto de que características como as citadas acima seriam hereditárias, de forma que a conclusão do argumento do autor é a de que elas devem ser socialmente enaltecidas para que se melhore as características da humanidade como um todo. De acordo com Galton ${ }^{31}$, as camadas 'mais débeis' da população têm uma maior tendência a reprodução e isso gera uma situação na qual as características da sociedade tenderiam a uma genética 'empobrecida' com o passar do tempo. A esse tipo de eugenia, dá-se o nome de eugenia positiva, que consiste no ato de selecionar características consideradas positivas para fazerem parte do conjunto de características herdadas por futuras gerações de indivíduos ${ }^{32}$, o que era selecionado independentemente de validação científica em relação à hereditariedade das características. A eugenia positiva é discutida e colocada em prática em certas situações peculiares no decorrer da história.

\footnotetext{
${ }^{29}$ MUKHERJEE, Siddhartha. The Gene, an intimate history. p. 73

30 Tradução livre: Todas as criaturas concordariam que é melhor ser saudável do que doente, vigoroso do que fraco, bem preparado do que mal preparado para a vida; em resumo, era melhor ser um bom espécime do que um ruim do seu tipo, qualquer que fosse esse tipo. O mesmo acontece com os homens. [...] Uma lista considerável de qualidades pode ser facilmente compilada de forma que quase todos, exceto os "errados", levariam em conta ao escolher os melhores espécimes de sua classe. Isso incluiria saúde, energia, habilidade, masculinidade e disposição cortês. GALTON, Francis. Eugenics: Its definition, scope, and aims. American Journal of Sociology, v. 10, n. 1, p. 1-25, 1904. p. 02.
}

${ }^{31}$ GALTON. Inquiries Into Human Faculty and Its Development. Londres: Everyman, 1907.

32 KEVLES, Daniel J. Eugenics and human rights. BMJ, v. 319, n. 7207, p. 435-438, 1999. p. 436. 
BOFF, Salete Oro; TOCCHETTO, Gabriel Zanatta. Carência de jurisdição sobre edição germinativa do genoma humano: riscos da ausência de ratio jurídica sobre a ferramenta CRISPR. Revista Eletrônica Direito e Política, Programa de Pós-Graduação Stricto Sensu em Ciência Jurídica da UNIVALI, Itajaí, v.15, n.3, $3^{\circ}$ quadrimestre de 2020. Disponível em: www.univali.br/direitoepolitica - ISSN 1980-7791

Em 1939, na cidade de Edimburgo, capital da Escócia, ocorreu o Sétimo Congresso Internacional de Genética, no qual um geneticista estadunidense chamado Hermann J. Muller publicou um texto apoiado por vinte outros geneticistas. O título de seu trabalho era "The Geneticists' Manifesto" (O Manifesto dos Geneticistas). O texto continha alegações ousadas, como as de que qualquer mãe consideraria uma honra receber sêmen de homens distintos, mesmo que esse material fosse proveniente de outrem que não seus companheiros, de forma que sociedade seria composta de pessoas com direito a serem gênios desde seu nascimento ${ }^{33}$, a ideia coloca a inseminação artificial como meio à eugenia positiva. O documento teria influenciado outro eugenista estadunidense pouco depois de sua publicação.

Robert K. Graham, un hombre que, ya pasados los setenta, había decidido dedicar su tiempo, su energía, que era mucha, y su dinero, que no era poco, ganado en el negocio de la óptica, a realizar un sueño y cumplir una misión. Ambas cosas, sueño y misión, aparecían en el titular de prensa: enriquecer el acervo genético de la humanidad. Hasta entonces, los bancos de esperma eran un simple remedio para la infertilidad. Este banco era distinto. No buscaba solo traer más niños al mundo. Se proponía traer niños mejores. ${ }^{34}$

Em 1980, em uma cidade chamada Escondido, no estado da Califórnia, nos Estados Unidos da América, Robert K. Graham fundou um banco de sêmen chamado "The Hermann J. Muller Repository for Germinal Choice" (O Repositório Hermann J. Muller para Escolha Germinal), cuja proposta era coletar esperma de vencedores de Prêmios Nobel científicos para colocar as amostras à disposição de

\footnotetext{
33 AYALA, Francisco José. ¿Clonar Humanos? Ingeniería genética y futuro de la humanidad. p. 117

34 Tradução livre: Robert K. Graham, um homem que, com mais de setenta anos, decidiu dedicar seu tempo, sua energia, que era muita, e seu dinheiro, que não era pouco, proveniente do ramo da ótica, para realizar um sonho e cumprir uma missão. Ambas as coisas, sonho e missão, apareceram na manchete da imprensa: enriquecer a herança genética da humanidade. Até então, os bancos de esperma eram um remédio simples para a infertilidade. Esse banco era diferente. Não estava apenas procurando trazer mais filhos para o mundo. Ele propunha trazer filhos melhores. RODRÍGUEZ LOPEZ, Blanca. ¿Qué hay de positivo en la eugenesia positiva?. Anuario de la Facultad de Derecho de la Universidad Autónoma de Madrid, v. 18, p. 141-170, 2014. p. 143.
} 
BOFF, Salete Oro; TOCCHETTO, Gabriel Zanatta. Carência de jurisdição sobre edição germinativa do genoma humano: riscos da ausência de ratio jurídica sobre a ferramenta CRISPR. Revista Eletrônica Direito e Política, Programa de Pós-Graduação Stricto Sensu em Ciência Jurídica da UNIVALI, Itajaí, v.15, n.3, $3^{\circ}$ quadrimestre de 2020. Disponível em: www.univali.br/direitoepolitica - ISSN 1980-7791

mulheres inteligentes ${ }^{35}$. Graham acreditava que uma genética fraca, gerada pela falta da presença da seleção natural na sociedade moderna, abria espaço para o desenvolvimento e proliferação de pensamentos comunistas, e que isso poderia ser resolvido por meio do referido banco ${ }^{36}$. Eventualmente, o banco desistiu da exclusividade de doadores ganhadores do referido prêmio e fechou no ano de 1999, registrando o nascimento de 215 crianças com esperma proveniente do banco, nenhuma geneticamente descendente de um ganhador do Prêmio Nobel $^{37}$.

Ao tempo que a eugenia positiva indica a seleção de características consideradas desejáveis, a eugenia negativa designa o lado oposto da moeda, ou seja, o ato de excluir dos descendentes a existência de características não desejáveis ${ }^{38}$. Isso significa, de forma objetiva, que ao tempo que a eugenia positiva se preocupa com as características que devem ser herdadas pelas futuras gerações, a eugenia negativa se preocupa com aquelas que não devem ser. Os episódios históricos nos quais a eugenia negativa figura como protagonista, que não são poucos, possuem comumente a característica de narrarem desrespeitos bárbaros a direitos e grosseiras generalizações científicas.

By the late 1930s, though, the glacial equanimity of the German public response to the sterilization program made Nazis bolder. Opportunity presented itself in 1939. In the summer of that year, Richard and Lina Kretschmar petitioned Hitler to allow them to euthanize their child, Gerhard. Eleven months old, Gerhard had been born blind and with deformed limbs. The parents - ardent Nazis hoped to service their nation by eliminating their child from the nation's genetic heritage. Sensing his chance, Hitler

\footnotetext{
${ }^{35}$ AYALA, Francisco José. ¿Clonar Humanos? Ingeniería genética y futuro de la humanidad. p. 126.

${ }^{36}$ RICHARDS, Martin. Artificial insemination and eugenics: celibate motherhood, eutelegenesis and germinal choice. Studies in History and Philosophy of Science Part C: Studies in History and Philosophy of Biological and Biomedical Sciences, v. 39, n. 2, p. 211-221, 2008. p. 219.
}

37 RICHARDS, Martin. Artificial insemination and eugenics: celibate motherhood, eutelegenesis and germinal choice. Studies in History and Philosophy of Science Part C: Studies in History and Philosophy of Biological and Biomedical Sciences, v. 39, n. 2, p. 211-221, 2008. p. $219 / 220$

38 CARDIN, Valéria Silva Galdino. Reprodução Humana Assistida e Parentalidade Responsável, conflitos e convergências entre os direitos brasileiro e português. Birigui - São Paulo: 2015. p. 65. 
BOFF, Salete Oro; TOCCHETTO, Gabriel Zanatta. Carência de jurisdição sobre edição germinativa do genoma humano: riscos da ausência de ratio jurídica sobre a ferramenta CRISPR. Revista Eletrônica Direito e Política, Programa de Pós-Graduação Stricto Sensu em Ciência Jurídica da UNIVALI, Itajaí, v.15, n.3, $3^{\circ}$ quadrimestre de 2020. Disponível em: www.univali.br/direitoepolitica - ISSN 1980-7791

approved the killing of Gerhard Kretschmar and then moved quickly to expand the program to other children. ${ }^{39}$

A Alemanha Nazista não foi nem a única localidade, nem o primeiro contexto no qual a eugenia negativa fora adotada como medida prática de eugenia negativa, apesar de ser comumente tratada como o exemplo mais cruel de aplicação do pensamento eugenista. Na primeira metade do século $X X$, as províncias de Alberta e British Columbia, no Canadá, a Dinamarca, a Suíça, a Alemanha, em grande parte dos Estados Unidos e o estado de Veracruz, no México, tinham vigentes políticas de esterilização ${ }^{40}$ com a finalidade de operar eugenia negativa $^{41}$.

$\mathrm{O}$ ato de pensar a eugenia a partir de Galton deve sempre vir acompanhado das reações que a primeira apresentação de seu trabalho "Eugenics: Its definition, scope, and aims" (Eugenia, sua definição escopo, e objetivos), no ano de 1904 na London School of Economics ${ }^{42}$. Na oportunidade, em meio a um contexto hostil à apresentação de Galton, William Bateson, considerado o pai da genética $^{43}$, colocou diante de Galton um argumento que até a atualidade embarga em absoluto a lógica eugenista: a eugenia propõe uma seleção com base em observações fenotípicas dos indivíduos com o intento de selecioná-los geneticamente ${ }^{44}$, e isso põe uma dupla falha à ratio eugenista: os fenótipos não apresentam suficientes ao ato de discriminar o genótipo de um indivíduo, da

\footnotetext{
39 Tradução livre: No final da década de 1930, porém, a equanimidade glacial da resposta pública alemã ao programa de esterilização tornou os nazistas mais ousados. A oportunidade se apresentou em 1939. No verão daquele ano, Richard e Lina Kretschmar solicitaram a Hitler que Ihes permitisse sacrificar seu filho, Gerhard. Com onze meses, Gerhard nasceu cego e com membros deformados. Os pais - nazistas fervorosos - esperavam servir à nação eliminando o filho da herança genética da nação. Pressentindo sua chance, Hitler aprovou o assassinato de Gerhard Kretschmar e depois se articulou rapidamente para expandir o programa para outras crianças. MUKHERJEE, Siddhartha. The Gene, an intimate history. p. 122.
}

40 POPENOE, Paul. The progress of eugenic sterilization. 2009. Disponível em: $<$ http://readingroom.law.gsu.edu/cgi/viewcontent.cgi?article $=1040 \&$ context=buckvbell $>$. Acesso em: 6 jan. 2020.

${ }^{41}$ Importante a colocação de que essa publicação fez parte dos documentos do caso Buck $v$ Bell, no qual a suprema corte americana declarou a legalidade da lei de esterilização do estado da Virgínia nos Estados Unidos da América, AYALA, Francisco José. ¿Clonar Humanos? Ingeniería genética y futuro de la humanidad. Madrid: Alianza editorial, 2017.), sendo a publicação datada de 2009, mas o documento redigido na década de 1930.

${ }^{42}$ GALTON, Francis. Eugenics: Its definition, scope, and aims. American Journal of Sociology, v. 10, n. 1, p. 1-25, 1904.

${ }^{43}$ MUKHERJEE, Siddhartha. The Gene, an intimate history. p. 62.

${ }^{44}$ MUKHERJEE, Siddhartha. The Gene, an intimate history. p. 74. 
BOFF, Salete Oro; TOCCHETTO, Gabriel Zanatta. Carência de jurisdição sobre edição germinativa do genoma humano: riscos da ausência de ratio jurídica sobre a ferramenta CRISPR. Revista Eletrônica Direito e Política, Programa de Pós-Graduação Stricto Sensu em Ciência Jurídica da UNIVALI, Itajaí, v.15, n.3, $3^{\circ}$ quadrimestre de 2020. Disponível em: www.univali.br/direitoepolitica - ISSN 1980-7791

mesma forma que um genótipo não garante expressões fenotípicas na maior parte das características postuladas como argumentos à eugenia de Galton.

Genótipo e fenótipo são dois conceitos básicos da biologia que indicam, de forma simples e objetiva, respectivamente, o conjunto de informações genéticas carregadas pelo indivíduo, e o conjunto de características que são capazes de descrever o indivíduo. Ao mencionar as características "health, energy, ability, manliness and courteous disposition" ${ }^{45}$, o autor comete o equívoco de colocar características que se distanciam muito de resultados objetivos de genótipos escolhidos ou não, que se aproximam muito mais de características que derivam de criações específicas ou uma vida financeiramente confortável. E as contradições superam ainda esse elemento, uma vez que Galton olvida muito do que eram as reais situações de grandes gênios da história da humanidade.

Quando se fala em seres humanos (ou de seres que se reproduzem de forma sexuada), esse material genético é, em regra, proveniente de uma mistura entre ambos os progenitores do indivíduo, e frequentemente responsável por muitas, mas não todas, das características fenotípicas do indivíduo. O fenótipo do indivíduo é um conjunto de características que se expressa em sua existência. No caso dos humanos, esse conjunto de características é especialmente mais complexo que as características genotípicas, expressando elementos que não possuem necessariamente qualquer associação com características genéticas, como "valores morales, preferencias estéticas, creencias religiosas y, en general, todos los rasgos tanto fisiológicos como conducturales de la persona, adquiridos por imitación, aprendisaje o cualquier otra manera" ${ }^{\prime 46}$. Essa característica se manifesta, inclusive, em situações de pessoas com propensão a importantes enfermidades e a que, ao mesmo tempo, podem expressar genótipos de inteligência importantes tanto para a humanidade, de forma histórica, quanto em comparação a seus pares.

\footnotetext{
${ }^{45}$ GALTON, Francis. Eugenics: Its definition, scope, and aims. American Journal of Sociology, v. 10 , n. 1 , p. $1-25,1904$. p. 02

46 Tradução livre: valores morais, preferências estéticas, crenças religiosas e, em geral, todos os traços fisiológicos e comportamentais da pessoa, adquiridos por imitação, aprendizado ou qualquer outro meio. AYALA, Francisco José. ¿Clonar Humanos? Ingeniería genética y futuro de la humanidad. p. 142.
} 
BOFF, Salete Oro; TOCCHETTO, Gabriel Zanatta. Carência de jurisdição sobre edição germinativa do genoma humano: riscos da ausência de ratio jurídica sobre a ferramenta CRISPR. Revista Eletrônica Direito e Política, Programa de Pós-Graduação Stricto Sensu em Ciência Jurídica da UNIVALI, Itajaí, v.15, n.3, $3^{\circ}$ quadrimestre de 2020. Disponível em: www.univali.br/direitoepolitica - ISSN 1980-7791

The list of "defective" geniuses went on and on: Newton was a sickly, fragile child; John Calvin was severely asthmatic; Darwin suffered crippling bouts of diarrhea and nearcatatonic depression. Herbert Spencer - the philosopher who had coined the phrase survival of the fittest - had spent much of his life bedridden with various illnesses, struggling with his own fitness for survival. ${ }^{47}$

No início da década de 1990 surge o primeiro mecanismo de intervenção genética capaz de 'balançar' a visão de que o termo 'eugenia' necessariamente apresenta intervenções que devem ser barradas pela bioética. A referida época marca a introdução de um procedimento chamado Diagnóstico Genético Préimplantação ${ }^{48}$.

As balizas sob as quais a bioética opera existem e se colocam, de um lado, sobre o medo que o uso descontrolado dos avanços colocados pela ciência desvirtuem o que pode ser tratado como 'essência' humana e, por outro, pelo receio de que o ato de não usar dos avanços tecnológicos para benefício da humanidade seja uma atitude que gere sofrimento humano. A edição genética, especialmente quando operada com o objeto do genoma humano, potencializa as consequências que uma ou outra decisão pode gerar à humanidade, não só pelo fato de que podem ser operadas edições eugênicas sem embasamento científico em seres humanos, mas também por tratar o ser humano como 'objeto'. Mesmo que sem delimitá-lo de forma precisa, enaltece drasticamente os problemas que podem ser gerados por eventuais equívocos na aplicação de quaisquer tipos de tratamentos.

\section{EDIÇÃO GERMINATIVA DO GENOMA HUMANO: COM BASE EM QUE, E ATÉ QUANDO, SE DEVE ESPERAR}

A história recente da edição genética, como já relatado, não é exatamente uma história que soma descobertas e invenções capazes de mudar as capacidades do

\footnotetext{
47 Tradução livre: A lista de gênios "defeituosos" continuava: Newton era uma criança doentia e frágil; João Calvino era severamente asmático; Darwin sofreu crises de diarréia e depressão quase catatônica. Herbert Spencer - o filósofo que cunhou a frase sobrevivência do mais apto - passou grande parte de sua vida acamado com várias doenças, lutando com sua própria aptidão para a sobrevivência. MUKHERJEE, Siddhartha. The Gene, an intimate history. p. 74.
}

${ }^{48}$ SERMON, Karen; VAN STEIRTEGHEM, André; LIEBAERS, Inge. Preimplantation genetic diagnosis. The Lancet, v. 363, n. 9421, p. 1633-1641, 2004. p. 1633. 
BOFF, Salete Oro; TOCCHETTO, Gabriel Zanatta. Carência de jurisdição sobre edição germinativa do genoma humano: riscos da ausência de ratio jurídica sobre a ferramenta CRISPR. Revista Eletrônica Direito e Política, Programa de Pós-Graduação Stricto Sensu em Ciência Jurídica da UNIVALI, Itajaí, v.15, n.3, $3^{\circ}$ quadrimestre de 2020. Disponível em: www.univali.br/direitoepolitica - ISSN 1980-7791

estado da técnica dos processos de edição, mas o relato de progressos científicos que diminuem margens de erro na edição genética e promovem o processo de acessibilidade em termos econômicos a ferramentas de edição genética. De fato, isso não é uma característica única da engenharia genética, um claro exemplo disso é o quão importante o simples avanço, previsto pela lei de Moore ${ }^{49}$ serve à explicação de muitos avanços sobre a popularização econômica e de uso das tecnologias. É possível que o maior fator de diferença socialmente observável seja consequência da acessibilidade, em termos de custo e simples facilidade de acesso, do que da criação de novas tecnologias em si.

Back in the 1980s, scientists had been content to edit individual genes at efficiencies that were just fractions of a percent. By the early 2000s, the efficiencies moved into the low-single-digit percentages, and it became possible to alter genes in a couple of new ways ${ }^{50}$. But with CRISPR, gene editing was now so powerful and multifaceted that it was often referred to as genome engineering ${ }^{51}$, a reflection of the supreme mastery that scientists held over genetic material inside living cells. ${ }^{52}$

As técnicas antigas de edição genética necessitavam de acesso a laboratórios extremamente sofisticados e recursos humanos qualificados, isso além de representarem custos inacessíveis para muitos laboratórios que teriam interesse em trabalhar com técnicas de edição genética ${ }^{53}$. Tudo isso muda drasticamente

${ }^{49}$ SCHALLER, Robert R. Moore's law: past, present and future. IEEE spectrum, v. 34, n. 6, p. 5259, 1997.

${ }^{50}$ As técnicas aqui mencionadas são as já mencionadas ZFN e TALEN.

51 O termo "engenharia genômica" é utilizado por parte da doutrina como mais adequado à descrição das capacidades que a técnica CRISPR apresenta ao estado da arte da edição genética, exatamente pelo fato de que a palavra "genoma" indica o conjunto de todo o material genético de um indivíduo, ao tempo que a palavra "genética" indica de forma genérica o objeto da edição, podendo indicar qualquer nível de alteração feita em material genético. Como opção metodológica, o presente trabalho não faz uso do termo "engenharia genômica" como diferente de "engenharia genética".

52 Tradução livre: Na década de 1980, os cientistas se contentavam com editar genes individuais em eficiências que eram apenas frações de um por cento. No início dos anos 2000, as eficiências passaram para as percentagens baixas de um dígito e tornou-se possível alterar os genes de duas maneiras novas. Mas com o CRISPR, a edição de genes agora era tão poderosa e multifacetada que costumava ser chamada de engenharia genômica, um reflexo do domínio supremo que os cientistas mantinham sobre o material genético nas células vivas. DOUDNA, Jeniffer A.; STERNBERG, Samuel H.. A Crack in Creation, Gene editing and the unthinkable power to control evolution. p. 100.

53 DOUDNA, Jeniffer A.; STERNBERG, Samuel H.. A Crack in Creation, Gene editing and the unthinkable power to control evolution. p. 111. 
BOFF, Salete Oro; TOCCHETTO, Gabriel Zanatta. Carência de jurisdição sobre edição germinativa do genoma humano: riscos da ausência de ratio jurídica sobre a ferramenta CRISPR. Revista Eletrônica Direito e Política, Programa de Pós-Graduação Stricto Sensu em Ciência Jurídica da UNIVALI, Itajaí, v.15, n.3, $3^{\circ}$ quadrimestre de 2020. Disponível em: www.univali.br/direitoepolitica - ISSN 1980-7791

após a entrada da tecnologia CRISPR no mundo de possibilidades dos pesquisadores. A tecnologia, além de permitir que alunos desde o nível de ensino médio pratiquem edições genéticas em laboratórios sem muitos recursos, chega ao extremo de apresentar ao mundo casos onde kits completos para a edição genética de bactérias são disponibilizados a consumidores pelo valor de 130 dólares americanos ${ }^{54}$.

No dia 8 de junho de 2012, Jeniffer Doudna, após um período de quase um ano de pesquisas em conjunto com o laboratório da pesquisadora Emmanuelle Charpentier, submeteu à revista Science o trabalho que se reconhece hoje como o primeiro trabalho científico sobre as capacidades de edição genética da ferramenta CRISPR ${ }^{55}$. Após um período de 20 dias, no dia 28 de junho de 2012, o trabalho fora aceito e, no dia 17 de agosto do mesmo ano, publicado ${ }^{56}$. No início ano seguinte, em 15 de fevereiro de 2013, outros dois trabalhos foram submetidos à mesma revista apontando às possibilidades de engenharia genética sobre células eucarióticas ${ }^{57}$, e descrevendo o procedimento de edição com CRISPR em células humanas ${ }^{58}$.

Em decorrência da publicação do primeiro trabalho ${ }^{59}$ e o segundo ${ }^{60}$ mencionados no parágrafo anterior, houve uma disputa patentária entre o Broad Institute of

54 DOUDNA, Jeniffer A.; STERNBERG, Samuel H.. A Crack in Creation, Gene editing and the unthinkable power to control evolution. p. 111

55 DOUDNA, Jeniffer A.; STERNBERG, Samuel H.. A Crack in Creation, Gene editing and the unthinkable power to control evolution. p. 85.

56 JINEK, Martin; CHYLINSKI, Krzysztof; FONFARA, Ines; HAUER, Michael; DOUDNA, Jennifer A.; CHARPENTIER, Emmanuelle. A programmable dual-RNA-guided DNA endonuclease in adaptive bacterial immunity. Science, v. 337, n. 6096, p. 816-821, 2012.

57 CONG, Le; RAN, F. Ann; COX, David; LIN, Shuailiang; BARRETTO, Robert; HABIB, Naomi; HSU, Patrick D.; WU, Xuebing; JIANG, Wenyan; MARRAFFINI, Luciano A.; ZHANG, Feng. Multiplex genome engineering using CRISPR/Cas systems. Science, v. 339, n. 6121, p. 819-823, 2013.

58 MALI, Prashant; YANG, Luhan; ESVELT, Kevin M.; AACH, John; GUELL, Marc; DICARLO, James E.; NORVILLE, Julie E.; CHURCH, George M.. RNA-guided human genome engineering via Cas9. Science, v. 339, n. 6121, p. 823-826, 2013.

59 JINEK, Martin; CHYLINSKI, Krzysztof; FONFARA, Ines; HAUER, Michael; DOUDNA, Jennifer A.; CHARPENTIER, Emmanuelle. A programmable dual-RNA-guided DNA endonuclease in adaptive bacterial immunity. Science, v. 337, n. 6096, p. 816-821, 2012.

${ }^{60}$ CONG, Le; RAN, F. Ann; COX, David; LIN, Shuailiang; BARRETTO, Robert; HABIB, Naomi; HSU, Patrick D.; WU, Xuebing; JIANG, Wenyan; MARRAFFINI, Luciano A.; ZHANG, Feng. Multiplex genome engineering using CRISPR/Cas systems. Science, v. 339, n. 6121, p. 819-823, 2013. 
BOFF, Salete Oro; TOCCHETTO, Gabriel Zanatta. Carência de jurisdição sobre edição germinativa do genoma humano: riscos da ausência de ratio jurídica sobre a ferramenta CRISPR. Revista Eletrônica Direito e Política, Programa de Pós-Graduação Stricto Sensu em Ciência Jurídica da UNIVALI, Itajaí, v.15, n.3, $3^{\circ}$ quadrimestre de 2020. Disponível em: www.univali.br/direitoepolitica - ISSN 1980-7791

MIT e a Universidade da Califórnia ${ }^{61}$. A disputa deriva do fato de que o pedido patentário feito junto ao USPTO (United States Patent Trademark Office ${ }^{62}$ ) pelo Broad Institute continha a descrição do ato de fazer edição genética em células eucariontes, enquanto o pedido patentário feito pela Universidade da Califórnia descreveu o processo de forma geral ${ }^{63}$. A "causa de pedir" da disputa era o elemento de "interferência"64, que significa dizer que a patente concedida ao Broad Institute impedia o livre gozo da patente concedida à Universidade da Califórnia. O resultado da disputa, até o momento, pelo fato de que a Suprema Corte Americana ainda não foi acionada no caso, foi uma vitória em primeira instância, em 15 de fevereiro de 2017, em julgamento do próprio USPTO, confirmado em segunda instância, em 10 de setembro de 2018, pela US Court of Appeals of the Federal Circuit ${ }^{65}$. Diversos pontos desse caso são de extrema importância para o cenário econômico da edição genética no mundo, um em especial para o presente trabalho:

The dispute centred on the rights to commercialize products developed by using the CRISPR-Cas9 system to make targeted changes to the genomes of eukaryotes - a group of organisms that includes plant and animals. Although many patents have been filed describing various aspects of CRISPR-Cas9 gene editing, the Broad Institute and UC patent applications were considered to be particularly important because they covered such a wide swath of potential CRISPR-Cas9 products. Investors have watched the case closely, even as they poured millions into companies that aim to develop medicines and crops using CRISPRCas9. The zeal with which both institutions defended their patents was unusual, says Jacob Sherkow, a legal scholar at New York Law School in New York City. Normally, he says,

\footnotetext{
${ }^{61} \mathrm{Na}$ disputa em questão, a Universidade da Califórnia figurou como polo junto à Universidade de Viena e a Professora Emmanuelle Charpentier.

62 Nome que se traduz para "Escritório de Patentes e Marcas Comerciais dos Estados Unidos", órgão responsável pela proteção patentária dentro do território estadunidense.

${ }^{63}$ LEDFORD, Heidi. Broad Institute wins bitter battle over CRISPR patents. Nature News, v. 542, n. 7642, p. 401, 2017.

${ }^{64}$ LEDFORD, Heidi. Broad Institute wins bitter battle over CRISPR patents. Nature News, v. 542, n. 7642, p. 401, 2017.

65 Traduzido de forma aproximada para "Corte de Apelações dos Estados Unidos do Circuito Federal" ou para "Corte de Recursos dos Estados Unidos do Circuito Federal". UNITED STATES OF AMERICA. Appeal from the United States Patent and Trademark Office, Patent Trial and Appeal Board; Case No. 106,048, 2018.
} 
BOFF, Salete Oro; TOCCHETTO, Gabriel Zanatta. Carência de jurisdição sobre edição germinativa do genoma humano: riscos da ausência de ratio jurídica sobre a ferramenta CRISPR. Revista Eletrônica Direito e Política, Programa de Pós-Graduação Stricto Sensu em Ciência Jurídica da UNIVALI, Itajaí, v.15, n.3, $3^{\circ}$ quadrimestre de 2020. Disponível em: www.univali.br/direitoepolitica - ISSN 1980-7791

such institutions would settle out of court before the case reached this point. ${ }^{66}$

A disputa e a intensidade com a qual ela se deu servem à demonstração do quão valiosa é a apropriação por meio de mecanismos de propriedade intelectual no caso em questão, quando se fala na democratização de uma ferramenta de edição genética que pode ser utilizada para a edição do genoma humano. Por mais que a ferramenta em si, ao menos quando se fala em valores unitários, não carregue cifras necessariamente interessantes o suficiente para a atração de investimentos multimilionários de capitais privados e públicos, o fato de ela ser utilizada em larga escala explica objetivamente o motivo pelo qual essa tecnologia é de grande valia.

O próximo capítulo da história que leva à chegada da moratória em relação à engenharia genética hereditária ocorre na já mencionada data de 26 de novembro de 2018, com o anúncio do nascimento das gêmeas chinesas com o gene CCR5 desativado ${ }^{67}$, edição genética com o objetivo de torná-las imunes ao vírus da HIV. A primeira consideração a ser feita sobre o caso, carregando o distanciamento necessário à análise da matéria, é que o ato de imprudência praticado por Jiankui, o cientista responsável pela edição genética feita no zigoto que gerou as gêmeas, não é um ato sem precedentes na história das práticas médicas, diga-se, na história das práticas médicas de sucesso.

\footnotetext{
66 Tradução livre: A disputa centrou-se nos direitos de comercializar produtos desenvolvidos usando o sistema CRISPR-Cas9 para fazer alterações direcionadas nos genomas dos eucariotos um grupo de organismos que inclui plantas e animais. Embora muitas patentes tenham sido registradas descrevendo vários aspectos da edição do gene CRISPR-Cas9, o Broad Institute e os pedidos de patente da Universidade da Califórnia foram considerados particularmente importantes porque cobriam uma faixa tão ampla de possíveis produtos CRISPR-Cas9. Os investidores acompanharam o caso de perto, mesmo quando despejaram milhões em empresas que pretendem desenvolver medicamentos e culturas usando o CRISPR - Cas9. O zelo com que ambas as instituições defendiam suas patentes era incomum, diz Jacob Sherkow, um especialista em direito da Faculdade de Direito de Nova York, na cidade de Nova York. Normalmente, ele diz, essas instituições resolveriam fora dos tribunais antes que o caso chegasse a esse ponto. LEDFORD, Heidi. Pivotal CRISPR patent battle won by Broad Institute. Nature News. Springer Nature America, Inc, 2018.
}

67 LANDER; BAYLIS, Françoise; ZHANG, Feng; CHARPENTIER Emmanuelle; BERG, Paul; BOURGAIN, Catherine; FRIEDRICH, Bärbel; JOUNG, J. Keith; LI, Jinsong; LIU, David; NALDINI, Luigi; NIE, Jing-Bao; QIU, Renzong; SCHOENE-SEIFERT Bettina; SHAO, Feng; TERRY, Sharon; WEI, Wensheng; WINNACKER, Ernst-Ludwig. Adopt a moratorium on heritable genome editing. Nature Comment, DOI: <. https://doi.org/10.1038/d41586-019-00726-5>. 2019. 
BOFF, Salete Oro; TOCCHETTO, Gabriel Zanatta. Carência de jurisdição sobre edição germinativa do genoma humano: riscos da ausência de ratio jurídica sobre a ferramenta CRISPR. Revista Eletrônica Direito e Política, Programa de Pós-Graduação Stricto Sensu em Ciência Jurídica da UNIVALI, Itajaí, v.15, n.3, $3^{\circ}$ quadrimestre de 2020. Disponível em: www.univali.br/direitoepolitica - ISSN 1980-7791

Talvez o caso paradigmático de testes inovadores feitos sem a certeza de sucesso e arriscando a vida do paciente com base em previsões que não necessariamente carregavam consigo provas de resultados positivos seja o caso do inventor da vacina, mecanismo hoje responsável pela preservação de incontáveis vidas humanas. Em 14 de maio de 1796, um médico chamado Edward Jenners, inventor da vacina, praticava o ato de inocular um garoto chamado James Phillips, com cerca de 8 anos de idade à época, com um patógeno letal, a varíola, sem possuir nenhuma evidência médica sólida de que o ato não levaria ao falecimento do garoto ${ }^{68}$. Na época, Janners foi intensamente julgado pela comunidade médica como um irresponsável que em decorrência de um 'palpite' colocara em risco a vida de uma criança ao tempo que hoje Jenners é tratado pela história da medicina como um grande descobridor, um herói da medicina ${ }^{69}$, e é importante a frieza da percepção de que esse pode ser também o caso do julgamento moral dispensado a He Jiankui.

His case is in such a way analogous to Jenner's that the success of his experiments and their side effects are highly uncertain and elude his ultimate control, making it a case of potential moral luck. Even though Jenner might not have crossed established ethics consensus, laws and regulations as obviously as He did, medicine in Jenner's century was not an "ethical wild West" either. ${ }^{70}$

Apesar da possibilidade de os feitos de Jiankui resultarem em uma situação de sorte moral, a imediata reação da comunidade científica foi o ato de pedir por uma moratória à edição genética hereditária em seres humanos ${ }^{71}$. A moratória nada mais é que um pedido específico para a espera (moratória = pedido de demora) para o intento de edição genética hereditária do genoma humano. A

68 SAND, Martin; BREDENOORD, Annelien L.; JONGSMA, Karin R. After the fact-the case of CRISPR babies. European Journal of Human Genetics, p. 1-4, 2019. p. 2.

69 SAND, Martin; BREDENOORD, Annelien L.; JONGSMA, Karin R. After the fact-the case of CRISPR babies. European Journal of Human Genetics, p. 1-4, 2019. p. 2.

70 Tradução livre: O caso dele é tão análogo ao de Jenner que o sucesso de seus experimentos e seus efeitos colaterais é altamente incerto e ilude seu controle final, tornando-o um caso de possível sorte moral. Embora Jenner possa não ter cruzado o consenso estabelecido em ética, leis e regulamentos tão obviamente quanto $\mathrm{He}$, a medicina no século de Jenner também não era um "oeste selvagem ético". SAND, Martin; BREDENOORD, Annelien L.; JONGSMA, Karin R. After the fact-the case of CRISPR babies. European Journal of Human Genetics, p. 1-4, 2019. p. 2.

71 LANDER et al. Ernst-Ludwig. Adopt a moratorium on heritable genome editing. Nature Comment, DOI: <. https://doi.org/10.1038/d41586-019-00726-5>. 2019. 
BOFF, Salete Oro; TOCCHETTO, Gabriel Zanatta. Carência de jurisdição sobre edição germinativa do genoma humano: riscos da ausência de ratio jurídica sobre a ferramenta CRISPR. Revista Eletrônica Direito e Política, Programa de Pós-Graduação Stricto Sensu em Ciência Jurídica da UNIVALI, Itajaí, v.15, n.3, $3^{\circ}$ quadrimestre de 2020. Disponível em: www.univali.br/direitoepolitica - ISSN 1980-7791

moratória se fez necessária ${ }^{72}$ em decorrência da carência de clareza que a declaração da cúpula internacional sobre edição genética ${ }^{73}$ verificou em seu texto sobre edição genética hereditária, frente ao acontecimento do nascimento das gêmeas com o genoma editado por CRISPR no final do ano de 2018.

A moratória se desenvolve como um texto de aplicabilidade facultativa, sem o intento de obrigar objetivamente países a segui-la, mas com o objetivo de conscientizar o mundo tanto dos riscos apresentados à sociedade pelo ocorrido, quanto ao fato de que esse tipo de prática se apresenta como inevitável nos próximos $\operatorname{anos}^{74}$. Entre outras entidades, a Sociedade Europeia de Genética Humana endossou a moratória, e o consenso da comunidade científica internacional é o de respeitá-la ${ }^{75}$. O prazo proposto pela moratória impreterível destaque desse elemento - é de apropriados cinco anos ${ }^{76}$, o que coloca o fato de que a chegada ao objetivo final desse tipo de procedimentos, considerando a apresentação das burocracias que a moratória coloca aos aceites específicos, deve acontecer a partir do ano de 2024, o que, para alguns cientistas, é uma espera que pode ser conservadora.

From a utilitarian perspective, no principled reasons exist to support a risk-averse 'precautionary' delay on an early-use HGGM attempt. However, a modest delay would have pragmatic benefits, a notion that has been given added impetus by the recent news of an ethically questionable and apparently not entirely successful first attempt at HGGM. I suggest that utility will be maximized if we kickstart the next biomedical revolution by proceeding not immediately but

72 LANDER et al. Ernst-Ludwig. Adopt a moratorium on heritable genome editing. Nature Comment, DOI: <. https://doi.org/10.1038/d41586-019-00726-5>. 2019.

73 BALTIMORE, David; BAYLIS, Françoise; BERG, Paul; DALEY, George Q.; DOUDNA, Jennifer A.; LANDER, Eric S.; LOVELL-BADGE, Robin; OSSORIO, Pilar; PEI, Duanqing; THRASHER, Adrian; WINNACKER, Ernst-Ludwig; ZHOU, Qi. On human gene editing: International summit statement. Washington DC: National Academy of Sciences, 2015.

74 LANDER et al. Ernst-Ludwig. Adopt a moratorium on heritable genome editing. Nature Comment, DOI: <. https://doi.org/10.1038/d41586-019-00726-5>. 2019.

75 SAND, Martin; BREDENOORD, Annelien L.; JONGSMA, Karin R. After the fact-the case of CRISPR babies. European Journal of Human Genetics, p. 1-4, 2019. p. 1.

76 LANDER et al. Ernst-Ludwig. Adopt a moratorium on heritable genome editing. Nature Comment, DOI: <. https://doi.org/10.1038/d41586-019-00726-5>. 2019. 
BOFF, Salete Oro; TOCCHETTO, Gabriel Zanatta. Carência de jurisdição sobre edição germinativa do genoma humano: riscos da ausência de ratio jurídica sobre a ferramenta CRISPR. Revista Eletrônica Direito e Política, Programa de Pós-Graduação Stricto Sensu em Ciência Jurídica da UNIVALI, Itajaí, v.15, n.3, $3^{\circ}$ quadrimestre de 2020. Disponível em: www.univali.br/direitoepolitica - ISSN 1980-7791

within around 1-2 years to intervene in the human germline. $^{77}$

É importante notar que os usos que o estado da arte da tecnologia de edição genética do genoma humano coloca, como reconhecido pela moratória ${ }^{78}$ e pelo

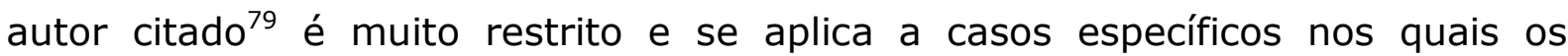
diagnósticos de pré-implantação para fertilização in vitro não são métodos com potencial para evitar que a prole seja protegida das doenças genéticas dos pais ${ }^{80}$. A diferença entre as duas ratios se encontra no fato de que, enquanto a moratória considera factível a espera de cinco anos para praticar a solução desse tipo de problema, Smith, a partir de uma ótica utilitarista da situação, acredita que não faria sentido esperar por tanto tempo.

\section{CONSIDERAÇÕES FINAIS}

Uma vez que se verifica que a discussão sobre edição genética só alcança o patamar de aplicação jurisdicional no momento em que se discute os direitos de Propriedade Intelectual sobre o processo de edição genômica, e não se trata de operar como direito as proibições/permissões em relação à ferramenta em específico, se vislumbra o nodo no qual o presente trabalho se desenvolve. É bem verdade que se verifica a operação de sanções (que poderiam ser chamadas de ato jurisdicional) de fato para o caso de He Jiankui, no entanto é importante mencionar que elas não foram operacionalizadas na forma de jurisdição

\footnotetext{
77 Tradução livre: A partir de uma perspectiva utilitária, não existem razões de princípios para apoiar um atraso 'preventivo' avesso a riscos em uma tentativa precoce de edição hereditária do genoma humano. No entanto, um atraso modesto traria benefícios pragmáticos, uma noção que recebeu um impulso adicional pelas notícias recentes de uma primeira tentativa eticamente questionável e aparentemente não totalmente bem-sucedida na edição hereditária do genoma humano. Sugiro que a utilidade será maximizada se iniciarmos a próxima revolução biomédica procedendo não imediatamente, mas dentro de 1 a 2 anos no ato de intervir na linha germinativa humana. SMITH, Kevin. Time to start intervening in the human germline? A utilitarian perspective. Bioethics, v. 34, n. 1, p. 90-104, 2020. p. 104.

78 LANDER et al. Ernst-Ludwig. Adopt a moratorium on heritable genome editing. Nature Comment, DOI: <. https://doi.org/10.1038/d41586-019-00726-5>. 2019.

79 SMITH, Kevin. Time to start intervening in the human germline? A utilitarian perspective. Bioethics, v. 34, n. 1, p. 90-104, 2020.

80 Os casos em que isso acontece são casos nos quais a doença deriva de genes recessivos carregados por ambos os pais, ou casos em que a doença deriva de genes dominantes em situação na qual um dos pais possui a característica de possuir um par desses genes.
} 
BOFF, Salete Oro; TOCCHETTO, Gabriel Zanatta. Carência de jurisdição sobre edição germinativa do genoma humano: riscos da ausência de ratio jurídica sobre a ferramenta CRISPR. Revista Eletrônica Direito e Política, Programa de Pós-Graduação Stricto Sensu em Ciência Jurídica da UNIVALI, Itajaí, v.15, n.3, $3^{\circ}$ quadrimestre de 2020. Disponível em: www.univali.br/direitoepolitica - ISSN 1980-7791

tradicional, mas como retaliações de um Estado autoritário (o governo chinês) e, dificilmente podem ser consideradas como suprimento do risco aqui verificado.

Em uma situação na qual se verifica a importância do assunto como apresentada nas seções 1 e 2 do presente trabalho, a presença única e exclusiva de uma moratória não vinculante, e dissenso científico sobre o tempo de espera, a metodologia dedutiva, seguida por meio da redação das três seções do desenvolvimento, que serviram o papel de confirmar a premissa maior e a premissa menor do argumento (seções 2 e 3, respectivamente) permite a confirmação da hipótese apresentada na introdução.

Sendo a hipótese de que a soma dos elementos de situação de "estado da arte" da tecnologia, do histórico humano de lidar com o assunto da genética humana, e a regulação aplicada à tecnologia, permitem concluir pela existência de carência de jurisdição sobre edição germinativa do genoma humano confirmada, é possível responder ao problema de pesquisa de forma positiva, sendo que o presente trabalho conclui pela existência de carência de jurisdição sobre o assunto da edição germinativa do genoma humano frente às possibilidades colocadas pela ferramenta CRISPR.

\section{REFERÊNCIAS DAS FONTES CITADAS}

AYALA, Francisco José. ¿Clonar Humanos? Ingeniería genética y futuro de la humanidad. Madrid: Alianza editorial, 2017.

BALTIMORE, David; BAYLIS, Françoise; BERG, Paul; DALEY, George Q.; DOUDNA, Jennifer A.; LANDER, Eric S.; LOVELL-BADGE, Robin; OSSORIO, Pilar; PEI, Duanqing; THRASHER, Adrian; WINNACKER, Ernst-Ludwig; ZHOU, Qi. On human gene editing: International summit statement. Washington DC: National Academy of Sciences, 2015.

BOFF, Salete Oro. Desafios da Inovação Tecnológica para Sustentabilidade Intergeracional. Sequência (UFSC), v. 41, p. 265-287, 2019.

BOFF, Salete Oro; ZAMBAM, Neuro J. (Bio) Derecho Y Responsabilidad como Delimitadores de la Biotecnología. Revista Brasileira de Estudos Políticos, v. 116, p. 375-402, 2018.

BOFF, Salete Oro; PEREIRA, Marta Carolina Gimenéz. Limites ao patenteamento de material humano na legislação brasileira. Revista do Programa de PósGraduação em Direito da UFBA, v. 28, p. 229-250, 2018. 
BOFF, Salete Oro; TOCCHETTO, Gabriel Zanatta. Carência de jurisdição sobre edição germinativa do genoma humano: riscos da ausência de ratio jurídica sobre a ferramenta CRISPR. Revista Eletrônica Direito e Política, Programa de Pós-Graduação Stricto Sensu em Ciência Jurídica da UNIVALI, Itajaí, v.15, n.3, $3^{\circ}$ quadrimestre de 2020. Disponível em: www.univali.br/direitoepolitica - ISSN 1980-7791

CARDIN, Valéria Silva Galdino. Reprodução Humana Assistida e Parentalidade Responsável, conflitos e convergências entre os direitos brasileiro e português. Birigui - São Paulo: 2015.

CONG, Le; RAN, F. Ann; COX, David; LIN, Shuailiang; BARRETTO, Robert; HABIB, Naomi; HSU, Patrick D.; WU, Xuebing; JIANG, Wenyan; MARRAFFINI, Luciano A.; ZHANG, Feng. Multiplex genome engineering using CRISPR/Cas systems. Science, v. 339, n. 6121, p. 819-823, 2013.

DOUDNA, Jeniffer A.; STERNBERG, Samuel H.. A Crack in Creation, Gene editing and the unthinkable power to control evolution. Boston: Mariner Books, 2017.

FOUCAULT, Michel. História da Loucura. Tradução de José Teixeira Coelho Neto. São Paulo: Perspectiva, 2017.

GALTON, Francis. Eugenics: Its definition, scope, and aims. American Journal of Sociology, v. 10, n. 1, p. 1-25, 1904.

. Inquiries Into Human Faculty and Its Development. Londres: Everyman, 1907.

GOULDNER, Alvin W. The norm of reciprocity: A preliminary statement. American sociological review, p. 161-178, 1960.

HABERMAS, Jürgen. O Futuro da Natureza Humana, a caminho de uma eugenia liberal? Tradução de Maria Benedita Bettencourt. Coimbra: Almedina, 2006.

HUXLEY, Aldous. Brave New World. London: Vintage Books, 1994.

JINEK, Martin; CHYLINSKI, Krzysztof; FONFARA, Ines; HAUER, Michael; DOUDNA, Jennifer A.; CHARPENTIER, Emmanuelle. A programmable dual-RNAguided DNA endonuclease in adaptive bacterial immunity. Science, v. 337, n. 6096, p. 816-821, 2012.

KEVLES, Daniel J. Eugenics and human rights. BMJ, v. 319, n. 7207, p. 435-438, 1999.

KNOEPFLER, Paul. GMO Sapiens: The Life-Changing Science of Designer Babies. Singapura: World Scientific, 2016.

LANDER, Eric S. The heroes of CRISPR. Cell, v. 164, n. 1-2, p. 18-28, 2016.

; BAYLIS, Françoise; ZHANG, Feng; CHARPENTIER Emmanuelle; BERG, Paul; BOURGAIN, Catherine; FRIEDRICH, Bärbel; JOUNG, J. Keith; LI, Jinsong; LIU, David; NALDINI, Luigi; NIE, Jing-Bao; QIU, Renzong; SCHOENE-SEIFERT Bettina; SHAO, Feng; TERRY, Sharon; WEI, Wensheng; WINNACKER, ErnstLudwig. Adopt a moratorium on heritable genome editing. Nature Comment, DOI: <. https://doi.org/10.1038/d41586-019-00726-5>. 2019. 
BOFF, Salete Oro; TOCCHETTO, Gabriel Zanatta. Carência de jurisdição sobre edição germinativa do genoma humano: riscos da ausência de ratio jurídica sobre a ferramenta CRISPR. Revista Eletrônica Direito e Política, Programa de Pós-Graduação Stricto Sensu em Ciência Jurídica da UNIVALI, Itajaí, v.15, n.3, $3^{\circ}$ quadrimestre de 2020. Disponível em: www.univali.br/direitoepolitica - ISSN 1980-7791

LEDFORD, Heidi. Broad Institute wins bitter battle over CRISPR patents. Nature News, v. 542, n. 7642, p. 401, 2017.

Pivotal CRISPR patent battle won by Broad Institute. Nature News. Springer Nature America, Inc, 2018.

MALI, Prashant; YANG, Luhan; ESVELT, Kevin M.; AACH, John; GUELL, Marc; DICARLO, James E.; NORVILLE, Julie E.; CHURCH, George M.. RNA-guided human genome engineering via Cas9. Science, v. 339, n. 6121, p. 823-826, 2013.

MUKHERJEE, Siddhartha. The Gene, an intimate history. London: Penguin Random House UK, 2016.

POPENOE, Paul. The progress of eugenic sterilization. 2009. Disponível em: $<$ http://readingroom. law.gsu.edu/cgi/viewcontent.cgi ?article $=1040 \&$ context $=$ bu ckvbell>. Acesso em: 6 jan. 2020.

RICHARDS, Martin. Artificial insemination and eugenics: celibate motherhood, eutelegenesis and germinal choice. Studies in History and Philosophy of Science Part C: Studies in History and Philosophy of Biological and Biomedical Sciences, v. 39, n. 2, p. 211-221, 2008.

RODRÍGUEZ LÓPEZ, Blanca. ¿Qué hay de positivo en la eugenesia positiva?. Anuario de la Facultad de Derecho de la Universidad Autónoma de Madrid, v. 18, p. 141-170, 2014.

SAND, Martin; BREDENOORD, Annelien L.; JONGSMA, Karin R. After the factthe case of CRISPR babies. European Journal of Human Genetics, p. 1-4, 2019.

SANDEL, Michael. Contra a Perfeição, ética na era da engenharia genética. Traduzido por Ana Carolina Mesquita. Rio de Janeiro: Civilização Brasileira, 2013.

SCHALLER, Robert R. Moore's law: past, present and future. IEEE spectrum, v. 34, n. 6, p. 52-59, 1997.

SERMON, Karen; VAN STEIRTEGHEM, André; LIEBAERS, Inge. Preimplantation genetic diagnosis. The Lancet, v. 363, n. 9421, p. 1633-1641, 2004.

SMITH, Kevin. Time to start intervening in the human germline? A utilitarian perspective. Bioethics, v. 34, n. 1, p. 90-104, 2020.

UNITED STATES OF AMERICA. Appeal from the United States Patent and Trademark Office, Patent Trial and Appeal Board; Case No. 106,048, 2018. 